\title{
(a) $w$
}

ISSN 2450-6486

www.ehs-ss.pl

DOI: 10.38014/ehs-ss.2020.3-1.16

УДК 37.01+140

\section{Дюбов ІДЬНИЦЬКА}

\section{"Освітньо-анадітична кодифікація" погдядів Івана Беха на співбуття "смис до-ціннісних" пошуків}

LIUBOV ILNYTSKA. "Educational and analytical codification" of Ivan Bekh's views on the coexistence of "meaning-value" searches. By means of "analytical coherence", the scientific idea of the famous Ukrainian teacher and scientist Ivan Dmitrievich Bekh, which is defined as the eventfulness of meaningful searches on the spiritual foundations of personal self-awareness, is analyzed. This study expands the already existing understanding of the "sense-value" conceptual spectrum thanks to the author's innovation - "educational-analytical codification".

Keywords: "educational-analytical codification", scientific approach of Ivan Bekh, meaningful searches, "analytical consistency".

Мета статті полягає у вивченні актуальної специфіки поглибленого співбуття смисло-ціннісного пошукового вектору, як "превалюючої понятійно-монадної структури", на необхідних засадах докладного дослідження першоджерельної бази, системне підгрунтя якої спирається на теоретичний внесок видатного українського науковця-діяча Івана Дмитровича Беха. 
Постановка проблеми у загальному вигляді. Вперше на основі застосування авторського підходу метододогічного спрямування гнучкого понятійного об'єднання "освітньо-аналітична кодифікація" проаналізовано погляди Івана Дмитровича Беха на структурне сполучення взаємозалежних ланок: "життя особистості" та "смислоціннісний пошук" у парадигмі такого відомого європейського інтелектуального напрямку, як філософія життя.

Анадіз останніх досліджень та пбдікацій. Вагомий твір І. Д. Беха "Особистість у просторі духовного розвитку" [1] започатковує традицію уніфікаціі смисло-ціннісних рівнів сконцентрованого навчально-виховного пошуку. Своєрідні наукові праці К. Журби, В. Дуб та Н. Більчук опридюднюють модернізовані підходи до вже класичної парадигми первинного понятійного навантаження так фаховотанатхненнопродемонстрованогоІваном_ДмитровичемБехом.

Виклад основного матеріалу. Одвічне прагнення педагогічної спільноти зафіксувати функціональні імплементації модернізованого гатунку життя на тлі незмінно-досконадих постулатів виховання започатковує цікаві теоретичні темпоритми. Все ж таки, суміжні фактори ускладненої аналітики вибудовують інший, більш істотно динамічний характер опридюднення комплексної верифікації моральнісних диспозицій по відношенню до амбівалентної лібералізації уніфікованих цінностей життя. Відтак, варто окремо дослідити масштабний досвід наукового опрацювання викривлених життєвих пропорцій у вимірах освітньо-виховної партитури суспільних прагнень, що вправно виявляе досконалі теоретичні спроби ствердити не уявні виміри понятійної самовпевненості, а оригінальний власний світ -"простір духовного розвитку" особистості. Отже, доробок Івана Дмитровича Беха $е$ мірилом відданого наполегливого пошуку унікальних понятійних сполучень - це слугує для інших поколінь зразком не спрощеного, тобто закономірного огляду фундаментадьних виховних істин, а набуттям необхідних рис постійного зростання, розширюючи власну амплітуду аналітичного навантаження на безпосередньо обране тематичне коло проблем.

Науковий спадок Івана Дмитровича Беха вартий ретельного вивчення, навіть кодифікації його оригінадьних понятійний умовиводів таких, як "співбуття" та "смисло-ціннісні" орієнтири особистіно-виховного поступу. По-особливому виразно думки i твердження I. Д. Беха проявилу свою афористичну амплітуду впливового наративу просвітницького бачення у такому об’ємному 
науковому творі, який має назву "Особистість у просторі духовного розвитку" [1]. До слова, слід навести чіткий лаконічний вираз I. Беха: "Моє життя - це моє співбуття" [1, с. 127]. Цим самим органічність наведеної думки відкриває духовно-содідарні площини гдибинного прагнення людини (вченого) до влучної єдності з істинним спадком педагогіко-філософічного тлумачення непізнаваної височини повсякчас актуальних сутностей - життя й буття.

Отже, наріжна сутнісна сфера парадигмадьного педагогічного аналізу проведеного І. Д. Бехом проявляє свою структурну взаємодію дотичних компонентів у виховній системі - "життя особистості в смисло-ціннісному пошуку". Ця об'ємна ідея, яка еволюціонувалася у аксіологічних чинниках моральнісного звучання закріплюе іманентно-просторовий екзістенціоналізм вкрай важливого сенсу винайденого Іваном Бехом особистісного самоусвідомденого вдосконалення. Тобто, аналітика освітологічного рівня виокремлює рухливі понятійні модуси до відчутного кодифікованого ритму науково-метододогічного ракурсу належної послідовності у найбільш сприятливому векторі до розкриття взаємодіючих паралельних ліній узгодженої стрункості педагогічного мислення. Відтак, це стосується виведеного I. Д. Бехом певного категоріадьного центру 3 таких важливих складових, як "життя особистості", та "смисло-ціннісний пошук". Дороговказом даного опрацювання є двоподюсний комплекс рівнозначних доповнюючих міжпарадигмальних ступені.

Таким чином, до кодифікованого ступеня "життя особистості" належать наступні рівні:

- "життя в енергетиці переживань";

- "життя особистості як причетність до буття";

- "життя як розвивальна вчинкова система";

- "життя в контексті готовності особистості до майбутнього";

- "життя особистості у величі духовності";

- "життя особистості у вимірі порядності - непорядності" [1].

Разом 3 тим, до другого кодифікованого ступеня - "смислоціннісний пошук" відносяться:

- "досягнення досконалості в достойному житті як цінності особистості";

- "морально-ціннісне спотворення в груповому житті";

Також у заданій системі існують опорні координати, що виводять обопідьно-суміжні умовиводи для передбаченого гармонійного існування двох зазначених ступенів, а саме: 
- "життя особистості в ціннісних проекціях";

- "життя особистості у ціннісній палкості" [1].

Спідьним знаменником запропонованої Іваном Дмитровичем конструкції є розгляд постулатів "філософії життя як моральної філософії" [1]. Саме завдяки цій моделі структурного розміщення тематично бдизьких проекцій запланованого академічного шляху виявляеться надійна послідовність поза хаотичного розвитку опрацьованих факторів, що акумулюють моральні принципи гуманістичної ідентичності у пластичності життєствердних педагогічних ідей ефективного функціонування. Зрештою, такий згаданий рівень першої кодифікації - "життя особистості як причетність до буття" оприлюднює намір автора наблизитися до ускладненого темпоритму співбуттєвого сенсу виховної одухотвореної модальності. За висловом Івана Дмитровича Беха: "Життя людини можна трактувати як більш чи менш усвідомлене створення нею цілісності із фрагментами буття" [1, с. 130]. Дюдинотворче бачення первісних сенсів буттєвої картини суб'єкта педагогічної дії - це модуляція вияву набутої далекоглядності, адже виходячи за межі наукознавчої методології Іван Дмитрович пропонує усвідомлено долучитися до відкриття перспективних елементів структурної концепції щодо побудови цілісного конгдомерату реалістичної картини світу виховного спрямування ціннісних аспектів досконадого життя.

Варто нагадати, що відомі представники такої широко знаної європейської течї, як філософія життя, теж залучади до своїх інтелектуальних трактувань істинно-смислових феноменів умовні моделі критичного погляду на неусвідомлену багатозначність буття під впдивом різних чинників життевих цінностей дюдини. Відтак, ідея нетривкого формування життєвої основи за Фрідріхом Ніцше є вольовий принцип неухидьної сили, що і формує надлюдину у готовності до глобальних викликів майбутнього. Проте, вже за Анрі Бергсоном стумулом до життя є творчий рушійний поступ, що насичується чуттєво-емоційним обсягом інтуїтивного світовідкриття. Теоретики даного напрямку здебільшого розмірковували над причинними ланками одновимірного становлення незаангажованого інтуїтивного відчуття буттєвих спалахів, чим над систематизацією співмірних елементів розвитку, що $є$ дотичними до розкриття потенціалу людського Духу.

Розглядаючи детально константний вимір Івана Дмитровича Беха "фідософію життя як моральної філософії", визначає як виховний 
простір духовного життествердження, яка на моделюючому структуруванні співбуттевих сенсів абсолютизуе рівнозначні кодифікації багаторівневих ступенів "смисло-ціннісного пошуку" та "життєвого визначення особистості". Згідно із цим входженням у аналітику освітологічного сенсу ціннісно відцентрованого життя, опридюдненні характеристики-рівні демонструють взаємоузгоджений порядок відкриття умовивідного наукового шляху співмірної індексації сутнісних значень моральнісної верифікації і одночасного пошуку особистісних перетинів у життєвих позиціях строкатого вибору необхідних для формування програмної основи для запропонованих I.Д. Бехом суджень.

Тим не менш, як не оминути той факт, який засвідчуе, що відомий український вчений у своїй виховній концептуальній системі перманентних принципів "смисло-ціннісних" педагогічних пошуків здебільшого спирався на професійні виважені багаторічні погляди фундаментального гатунку, тоді як аналогічну пошукову схему використовують у подібний спосіб й інші вітчизняні науковці. Наразі, дослідження спільної понятійної ланки, такої як смисло умовивідні показники ціннісної життедіяльності стимулює звернути увагу і на однокореневі пошукові пропозиції. Наприклад, при встановленні освітніх вважелів "ціннісно-смислової характеристики" становлення самоусвідомленого професійного розвитку майбутніх педагогів віднаходжується систематизуюча ступінь двоподюсного розмежування внутрішніх акцентів, тобто, як засвідчує автор: "у процесі професійного навчання формуються певні структурнозмістовні особливості ціннісно-смислової сфери студентів, яка вкдючає два основні компоненти - ціннісні орієнтації і систему особистіних смислів" [2, с. 237].

Варто погодитись, що і кодифікований ступінь Івана Дмитровича - категоріальний конгломерат "смисло-ціннісного пошуку" коредюєтьсязекстраподяцієюфілософііжиттянаморадьніпредикати іншого умовивідного виміру - "життя особистості" по відношенню до прорпорційної акумуляції власної науково-методологічної основи. Тоді, як "ціннісно-смислової сфера особистості" нанизуе пріоритети відповідної предметно-закономірної опосередкованості: "потреби, мотиви, інтереси, самосвідомість, спрямованість, ідеї, ідеали та цінності" [2, с. 237]. Згідно із цим положенням, освітньо-аналітичний аналіз дозволяе вказати на те, що однакова розгалуженість понятійного напрямку акцентується на типовому двошаровому 
умовивідному утворенні. Проте, оприлюднена мета рефлексивних підходів зводиться до заздалегідь по-різному сформованого вказівного завдання. Адже, між іншим, попри критичні зауваження, насамперед потрібно обміркувати вмотивовану вірогідність по загальній суті викладення та функціональності впровадження, що є більш вагомим для педагогічної науки - виявити характеристику формалістичного наукового малюнку до ситуативної систематизації однакових чинників, чи підказати за допомогою духовного просвітлення важливий шлях до накопичення сенсів олюднених життям ціннісних пріоритетів морадьнісного співбуття?..

Іван Дмитрович детально пояснюе понятійні наголоси співбуття, як органічної цілісності специфічного обсягу впливої абсолютизації. "Відтак буття як реадьно існуюча дійсність перетворюється на співбуття, тобто на неіндеферентний для особистості світ". У деякій мірі ця думка засвідчуе наближення до категорізації найвищих значень буття у доповнюючому сенсі і допомагає відкривати можливості кодифікаціі рефлексивних положень порушених нюансів на співмірність причетності життєвого особистісного наміру на вивищення оточуючих прагнень до рівня монадності всесвіту. У цьому разі підхід І.Д. Беха до індексаціі дотичних до буттевості схоплень надзвичайного гатунку осягає в такому ракурсі зазначеної проблематики споріднені внутрішні процеси метафізичного характеру. Іван Дмитрович наголошуе, що "у терміні "співбуття" зафіксовано момент причетності суб'єкта до чогось. Отже, співбуття - це єдність певного предмета та дюдини, його співвднесеність із нею" [1, с. 126]. Виразним чином підкреслюється широке - буттєве коло спів-ціннісних модуляцій непорушного, знову ж таки, буттєвого розвитку взаємозалежних рівнів індивідуально-неподільного внеску здатності осягнути неможливе у наближенні до безкінечного. При реконструкції моделі співбуття це відбувається завдяки розчиненню власного багатоманіття знаків буття у вищій сутності життя та метафізичному окресленні непорушності суголосних витоків 3 морально-ціннісним рівнем закономірностей удосконалення людини, як педагогічного погляду на встановлення тематичного завдання вводити "понятійну категорію" співбуття до теоретичних основ виховання.

Разом 3 тим, завдяки кодифікованим способам аналітики співбуття проявдяе себе, як особлива цілісність "превадюючої понятійно-монадної струкутури", що дає спроможність задля 
того, щоб вправно створювати мождивості стосовно впровадження світоглядних правид по відношенню до відновдення особистісних пріоритетів благонадійного життя. Адже, як продовжуе свою думку Іван Дмитрович Бех: "у ситуації співбуття людина наділяе об'єкт дійсною цінністю для себе" [1, с. 126]. Ціннісні пріоритети етичної сутності віднаходять збалансовану стратегію "буття в собі, як відкриту цінність у одновимірному підпорядкуванні" i "буттеві виміри світоглядного долучення" до поза матертіального започаткування. Проте, шкала ціннісних вимірів різниться авторським ставленням до вмотивованих позицій смисло-ціннісного пошуку.

До фахових роздумів І. Д. Беха з цього приводу доцільно додати і теоретичні погляди Н. А. Більчук, яка здійснює контекстний аналіз безпосередніх принципів дюдського співбуття. Бі дьчук Н. А. зазначає, що "ускладнення структури соціального і культурного простору, трансформація цінностей і моральних ідеалів індивідуальної та колективної свідомості спонукає до пошуків відповідей на питання про основні принципи спів-буття індивідів та основи цілісності людської спільноти" [3, с. 124]. За цим підходом понятійна цілісність двопланових частин співбуттєвого єднання залучена і до гармонізації соціальних та індивідуальних спонукальних модусів якісного співіснування. Н. Більчук пояснюе, що протилежні рівні зосереджені на ціннісному входженні у набутий зміст буттєвого горизонту, що наслідуе класичні механізми аргументації прибічників кордоцентризму, які вважали за потрібне відображати низку людських чеснот, притаманних істинному овододінню змістовними планами одухотвореного розвитку, де первинні сенси передбачають наслідувати вміння готовності до формування спільного ціннісного значення. Як приклад, слід процитувати Н. Більчук: "підкреслюючи гідність індивідуального виміру особи, кордоцентризм звертається до проблеми їі взаємин з іншими людьми і вказує, що саме любов до бдижнього є умовою дюдського співбуття".

Кордоцентричні принципи етичного регулювання теж знаходять відображення у смисло-ціннісних пошуках відповідних понятійних еквівалентів. Послідовниця педагогічних ідей І.Д. Беха К. О. Журба вводить до своєї концептуальної стратегї плекання морально-відповідальних навичок у учнів основної та старшої школи такий ціннісний спектр смисложиттєвих пріоритетів, як яюбов і справеддивість [4]. Отже, "підкреслюючи гідність індивідуадьного виміру особи, кордоцентризм звертається до проблеми ії взаємин 
з іншими дюдьми і вказує, що саме любов до ближнього є умовою людського співбуття" [3, с. 105]. Акцентований ціннісний пошук найвищих сенсів сумісного гармонійного руху поєднується із смисложиттевими засадами особистісного вибору прищеплених теоретичних розробок професійного педагогічного досвіду. Відтак, завдяки включенню цього етапу накладання анадітичних викладок кодифікованого структурування відкривається спосіб одухотвореного осмислення витоків поглибленого передбачення результатів особистісного розвитку, але у випадку аналізу встановлених І.Д. Бехом багаторівневих ідеалів співбуття смисло-ціннісних пошуків, встановдюеться понятійна кодифікація життевих постулатів цілісного "духовного простору розвитку".

Висновки. Кредо устремдінь видатного педагога та вченого Івана Дмитровича Беха дотично до ціннісних значень надзвичайного призначення, де абсолютизація класичних істин кодифікуеться сенсами саме "філософії життя як моральної філософії" [1]. Насамкінець варто зазначити, що методологія освітньо-аналітичного узгодження дозволяе виявляти перспективні горизонти для переосмислення вказівних положень щодо розвитку освіти і науки в цілому, навіть у академічному колі вивчення універсальних педагогічних джере $л$ направленням до багатозначного рівня сучасного життя.

\section{References:}

1. Бех І. Д. Особистість у просторі духовного розвитку. К.: Академвидав, 2012. $256 \mathrm{c}$.

2. Дуб В. Ціннісно-смислові характеристики майбутніх педагогів. Актуальні питання гуманітарних наук: міжвузівський збірник Дрогобицького держ. пед. університету. 2017, № 12. С. 235 - 244.

3. Більчук Н. Л. Проблема співбуття людини та суспільства в кордоцентризмі. Гуманітарний часопис. 2004, № 1. С. 104 - 107.

4. Журба К. О. Аюбов як смисложиттева цінність учнів основної та старшої школи. Наукові записки [Ніжинського держ. університету ім. Миколи Гоголя]: Психолого-педагогічні науки. 2014, № 4. - С. 16 - 21.

\section{Transliteration of References:}

1. Bekh I. D. (2012). Osobystist u prostori dukhovnoho rozvytku. K.: Akademvydav. $256 \mathrm{~s}$.

2. Dub V. (2017). Tsinnisno-smyslovi kharakterystyky maibutnikh pedahohiv. 
Aktualni pytannia humanitarnykh nauk: mizhvuzivskyi zbirnyk Drohobytskoho derzh. ped. universytetu. № 12. S. 235 - 244.

3. Bilchuk N. L. (2004). Problema spivbuttia liudyny ta suspilstva v kordotsentryzmi. Humanitarnyi chasopys. № 1. S. 104 - 107.

4. Zhurba K. O. (2014). Liubov yak smyslozhyttieva tsinnist uchniv osnovnoi ta starshoi shkoly. Naukovi zapysky [Nizhynskoho derzh. universytetu im. Mykoly Hoholia]: Psykholoho-pedahohichni nauky. № 4. S. 16 - 21.

The Author

Liubov Ilnytska

Candidate of Philosophical Sciences,

Ukrainian Humanities Institute,

Kyiv, Ukraine

E-mail:lvilnitsa@gmail.com

Abstracts

ДЮБОВ ІЛЬНИЦЬКА. "Освітньо-аналітична кодифікація" погдядів Івана Беха на співбуття "смисло-ціннісних" пошуків. Засобами "аналітичного узгодження" проаналізовано провідну наукову ідею відомого украӥнського педагога та вченого Івана Дмитровича Беха, яка стосуеться визначення співбуття "смисло-иціннісних" пошуків на духовних засадах особистісного самоусвідомлення. Дослідження розширюе фаховий погляд на понятійні виміри "смисло-циіннісного" волевияву завдяки такому авторському нововведенню, як: "освітньо-аналітична кодифікація".

Ключові слова: освітньо-аналітична кодифікація, науковий доробок І.Д. Беха, смисло-иіннісні пошуки, "аналітичне узгодження".

АЮБОВЬ ИЯЬНИЦКАЯ. "Образовательно-аналитическая кодификация" взгдядов Ивана Беха на событие "смысло-ценностных" поисков. Средствами "аналитеческой согласованности" проанализировано научную идею известного украинского педагога и ученого Ивана Дмитриевича Беха, которая определяется, как событийность "смысло-иеннносных" поисков на духовных основах личностной самоосознанности. Данное исследование расииряет уже сложившиеся понимание "смысло-иенностного" понятийного спектра благодаря авторскому нововведению - "образовательно-аналитическая кодификация". 
Ключевые слова: образовательно-аналитическая кодификация, научный подход И. Д. Беха, смысло-иенностные поиски, "аналитическая согласованность".

LUBOW ILNYCKA. „Edukacyjno-analityczna kodyfikacja” poglądów Iwana Becha na wspótistnienie poszukiwań "wartościowo-znaczeniowych". Wiodaca idea naukowa słynnego ukraińskiego pedagoga i naukowca Iwana Dmytrowycza Becha, która dotyczy definicji wspótistnienia poszukiwań "wartościowoznaczeniowych" na podstawie duchowych zasad samoświadomości, została przeanalizowana przy pomocyśrodków "koordynacji analitycznej”. Badanie poszerza profesjonalne spojrzenie na koncepcyjne wymiary „wartościowoznaczeniowego" wyrażania woli dzięki takim autorskim innowacjom, jak: "kodyfikacja edukacyjno-analityczna".

Stowa kluczowe: kodyfikacja edukacyjno-analityczna, osiagnięcia naukowe I.D. Becha, poszukiwanie wartościowo-znaczeniowe, ,koordynacja analityczna". 